\title{
Spatial Modeling of Forest Cover Change in Kubu Raya Regency, West Kalimantan
}

\author{
Hanifah Ikhsani ${ }^{1}$, I Nengah Surati Jaya ${ }^{2^{* *}}$, Muhammad Buce Saleh ${ }^{2}$
}

\author{
'Graduate School of Bogor Agricultural University, Dramaga main Road, Campus IPB Dramaga, Bogor, Indonesia 16680 \\ ${ }^{2}$ Department of Forest Management, Faculty of Forestry, Bogor Agricultural University, Academic Ring Road, Campus IPB \\ Dramaga, PO Box 168, Bogor, Indonesia 16680
}

Received October 12, 2018/Accepted December 26, 2018

\begin{abstract}
Forest cover change is one of the environmental issues that continually gotten international attention. This study describes how to develop a spatial model of this change in each village-based typology by considering various biophysical and social-economic factors. The village typologies were investigated by applying the clustering analysis approach. The objective of this study was to develop the spatial model and to identify the driving forces of forest cover change by the village in Kubu Raya Regency of West Kalimantan. Based on the proportion of forest in 2015 , the study found that there are two village typologies within the study area with $81 \%$ overall accuracy $(O A)$. The Typology 1 (T1) which has low change rate of 5,001.8 ha year ${ }^{-1}$ consisted of 56 villages, while the Typology 2 (T2) which has high change rate about 8,050.6 ha year ${ }^{-1}$ covered 34 villages. The study also recognized that the most significant driving forces of change in $T 1$ were the distance from rivers $\left(X_{2}\right)$ and settlements $\left(X_{3}\right)$, whereas in $T 2$ were the distance from roads $\left(X_{1}\right)$ and the edge of the forest in $2015\left(X_{0}\right)$. The best spatial model of the change are $Y=-$ $0.01+0.0001 X_{2}+0.0004 X_{3}$ with $\mathrm{OA}$ of $83 \%$ and mean deviation (SR) $10.5 \%$ for T1 and $Y=0.02+0.0001 X_{1}$ $0.0002 X_{9}$ with $O A 53 \%$ and SR $13.3 \%$ for T2. The study concludes that the proximity from the center of the human activities holds a significant influence on the behavior offorest cover changes.
\end{abstract}

Keywords: clustering, driving force, lowland forest, village typologies

*Correspondence author, email: ins-jaya@apps.ipb.ac.id

\section{Introduction}

The issue of deforestation and forest degradation in Indonesia has been a long story and still a debatable issue. However, it is increasingly threatened by the demands of new land for other uses, which are the implications of economic and population growth. Even with the alarming rates, certain forest areas were still decreasing within the last three decades (FWI 2014; KLHK 2017). The primary forest cover changes in Indonesia have reached a rate of 0.84 million ha or 700,000 ha per year (Margono et al. 2014). Up to now, forest cover change has been a very sensitive issue becauseit will lead to climate change, while on the other hand there is a high necessity of opening less productive areas for development purposes (Siswoko 2008; IPCC 2013). Based on several studies that have been conducted in regions such as Sumatra (Sulistiyono et al. 2015; Wijaya et al. 2015; Albar et al. 2016), behaviors and characteristics on certain areas are varied significantly according to their biophysical, economic, social, and even political conditions.

Forest cover change might occur due to many factors from biophysical characteristics, socioeconomic, and cultural conditions, even due to the political situation within the community (Geist et al. 2002; Sloan et al. 2015). In
Indonesia, the changes that occurred within each region are varied in terms of their rates and the driving forces causing the dynamic change. Therefore, an estimation method using spatial approaches was expected to describe a more reliable relationship among various forces as mentioned to the forest cover change that was happening in theIndonesian region. Estimation of the change using spatial approaches could be found in Sulistiyono et al. (2015), Albar et al. (2016), and Wijaya et al. (2015). In this studytypology was done to obtain the more reliable model, all villages were grouped into a more homogenous class, which then is referred to as village typology. Typology can be defined asthe grouping of study units into a subpopulation that is homogenous. The use of typology has been conducted in several studies and was considered necessarily effective in increasing the accuracy of the model and identifying the causing or supporting forces of forest cover changes within an area. Several studies showed that the change rates were in line with the typology of the area (Valbuena et al. 2008; Lastini 2012; Pincus et al. 2015). Typology would also make it easier to consider the triggering factors and spatial patterns of the forest cover changes (Valbuena et al. 2008; Sulistyono etal.2015). 
In this study, the smallest unit of administrative boundary used asobservationwas the village. It was expected that within this level, the forest cover change would relate with their socioeconomic, cultural, and even institutional conditions of each village area. Hence, it would be very important to conduct a typology study of these changes within the village administrative area. This would expect to increase the accuracy of the spatial model of forest cover change that wasdeveloped for each region.

Research in forest cover change in Indonesia would be important because it would also consider the regional planning act at the regency level that has been enactedsince the Autonomy Law Regions No. 22 in 1999, as well as the Autonomy Law Regions in year 2000. Also, the studies done in Indonesia regarding these changes are very few, mostly only for province or island region levels (Sulistiyono et al. 2015; Wijaya et al. 2015; Albar et al. 2016). One of the islands in Indonesia that often became national and global attention was the Island of Borneo because of the very high rates of changes that were happening within the island. West Kalimantan Province was also one of the areas in Borneo Island that had a very high rate of changes that was happening within that area. This study emphasizes the change in Kubu Raya Regency which was one of the regencies in West KalimantanProvince of Borneo Island that had high rates of the change. Kubu Raya Regency area was regency dominated by wetlands, swamp of forest ecosystems, and mangrove forest that was a forest cover within lowland forest areas.

Considering the information mentioned above, the main objective of this study was to develop a spatial model of the forest cover change, specifically in identifying the village typologies and the driving forces causing the changes in Kubu Raya Regency, West Kalimantan. This spatial modeling was expected to explain the spatial coverage of forest cover change and driving factors causing the change within each typology within this area.

\section{Methods}

The study was carried out from September 2017-April 2018. This study was in Kubu Raya Regency, West Kalimantan Province, Indonesia which was geographically located in $108^{\circ} 35^{\prime}-109^{\circ} 58^{\prime} \mathrm{BT}$ and $00^{\circ} 44^{\prime} \mathrm{LU}-10^{\circ} 01^{\prime} \mathrm{LS}$. Kubu Raya Regency has nine districts and 118 villages. This study was also carried out in the Remote Sensing Laboratory of Faculty of Forestry, IPB Bogor, Indonesia.

In this study, Global Positioning System (GPS), camera, tally sheet, and stationery were used for fields observation and conducting inspections. For the processing, the hardware used was a set of computers with software ArcGIS 10.1, Erdas imagine 9.1, and Minitab 17. The main data that were used for this research were Landsat TM Multitemporal Images acquired in March 5 year 2011 and February 12 year 2015, land cover data of 2000 and 2015 issued by the Ministry of Environment and Forestry (KLHK), district-level statistical data of Kubu Raya Regency in 2009 and 2016, administrative data published by the Geospatial Information Agency (BIG), and field observation data.

\section{Selection of typologyvariables}

Forest cover change can be defined as the change in forest cover conditions from forest to non-forest areas. The analysis of the change rates was done by overlay each land cover each period. The development of the typology of the change area in Kubu Raya Regency was conducted using a quantitative approach with the clustering method. Cluster analysis was a technique designed to find similarity in a data set. Cluster analysis aims to find the category structure that is in accordance with the observation (finding the natural group).Clustering method was used to find the grouping patterns of a village. In this analysis, the selection of variables was conducted through correlation analysis to define if there were closeness and direct relationship between two variables that were used as variables for the construction of typology (Lastini 2012; Sulistiyono et al. 2015; Albar et al. 2016 2012). This study excludes the forest cover changes in industrial plantation forests (hutan tanaman industri, HTI) from this calculation. This research uses variables that were based on biophysical and socio-economic conditions of the community within the village in the year 2000-2015.

The independent variable that was used for developing typology were proportion of forest in $2000\left(\mathrm{X}_{1}\right)$, proportion of forest in $2015\left(\mathrm{X}_{2}\right)$, population year 2000-2015 ( $\left.\mathrm{X}_{3}\right)$, population rate of $2000-2015\left(\mathrm{X}_{4}\right)$, the pace of the number of schools in 2000-2015 $\left(\mathrm{X}_{5}\right)$, number of school year 2000$2015\left(X_{7}\right)$, the pace of the number of students in 2000-2015 $\left(X_{8}\right)$, number of student year 2000-2015 $\left(X_{8}\right)$, the rate of teachers in 2000-2015 $\left(\mathrm{X}_{9}\right)$, number of teachers from 2000-2015 $\left(\mathrm{X}_{10}\right)$, the rate of doctors in 2000-2015 $\left(\mathrm{X}_{11}\right)$, number of doctors in 2000-2015 $\left(X_{12}\right)$, the rate of number of community health center in 2000-2015 $\left(\mathrm{X}_{13}\right)$, and the number of community health center in 2000-2015 ( $\left.\mathrm{X}_{14}\right)$. As for the dependent variable was the forest cover change rate. All the $\mathrm{X}$ variables went through correlation analysis which resulted in 14 variables produced from the analysis. The independent variables are then analyzed again using correlation test with the dependent variable. The correlation test matrix variable is presented in Table 1.

Development offorest cover change typology Development of village typology was done using a clustering approach with standardized Euclidean distance (Valbuena et al. 2008; Lastini 2012). Euclidean distance was the type of distance measurement in cluster analysis that is most commonly used to measure the distance from a data object to the cluster center. Euclidean distance was a geometric distance between two data objects so that the closer the distance the more it looks like a data object. The clustering process was then analyzed graphically using dendrogram with the average linkage method. To evaluate the indication of multicollinearity between the causing factors and the driving factors, as well as between the ratio of forests to the driving factors and causes, therefore a correlationtest was conducted (Table 1).

The analysis shows that there were two driving factors that were highly correlated with the proportion of forest, namely the proportion of forest in $2000\left(\mathrm{X}_{1}\right)$ and the proportion of forest in $2015\left(\mathrm{X}_{2}\right)$. However, since between $\mathrm{X}_{1}$ 
Table 1 Coefficient of correlation the driving factors and the rate of forest cover change

\begin{tabular}{llllllllllllllll}
\hline & \multicolumn{1}{c}{$\mathrm{Y}$} & $\mathrm{X}_{1}$ & $\mathrm{X}_{2}$ & $\mathrm{X}_{3}$ & $\mathrm{X}_{4}$ & $\mathrm{X}_{5}$ & $\mathrm{X}_{6}$ & $\mathrm{X}_{7}$ & $\mathrm{X}_{8}$ & $\mathrm{X}_{19}$ & $\mathrm{X}_{10}$ & $\mathrm{X}_{11}$ & $\mathrm{X}_{12}$ & $\mathrm{X}_{13}$ & $\mathrm{X}_{14}$ \\
\hline $\mathrm{Y}$ & 1.0 & & & & & & & & & & & & & & \\
$\mathrm{X}_{1}$ & -0.3 & 1.0 & & & & & & & & & & & & \\
$\mathrm{X}_{2}$ & -0.8 & 0.7 & 1.0 & & & & & & & & & & & \\
$\mathrm{X}_{3}$ & -0.1 & 0.1 & 0.2 & 1.0 & & & & & & & & & & \\
$\mathrm{X}_{4}$ & 0.0 & -0.2 & -0.1 & -0.3 & 1.0 & & & & & & & & & \\
$\mathrm{X}_{5}$ & 0.0 & 0.0 & 0.0 & -0.1 & 0.5 & 1.0 & & & & & & & & \\
$\mathrm{X}_{6}$ & -0.1 & -0.1 & 0.0 & -0.2 & 0.7 & 0.4 & 1.0 & & & & & & & \\
$\mathrm{X}_{7}$ & 0.1 & 0.0 & 0.0 & -0.2 & 0.8 & 0.7 & 0.7 & 1.0 & & & & & & \\
$\mathrm{X}_{8}$ & 0.0 & -0.2 & -0.1 & -0.2 & 0.9 & 0.6 & 0.8 & 0.9 & 1.0 & & & & & \\
$\mathrm{X}_{9}$ & -0.1 & -0.1 & 0.0 & -0.2 & 0.7 & 0.4 & 0.8 & 0.6 & 0.7 & 1.0 & & & & \\
$\mathrm{X}_{10}$ & 0.0 & -0.2 & -0.1 & -0.2 & 0.9 & 0.5 & 0.9 & 0.8 & 0.9 & 0.7 & 1.0 & & & \\
$\mathrm{X}_{11}$ & 0.0 & 0.0 & 0.0 & -0.2 & 0.3 & 0.3 & 0.2 & 0.4 & 0.4 & 0.2 & 0.3 & 1.0 & & & \\
$\mathrm{X}_{12}$ & 0.0 & -0.1 & 0.0 & -0.2 & 0.4 & 0.2 & 0.4 & 0.2 & 0.4 & 0.2 & 0.4 & 0.5 & 1.0 & & \\
$\mathrm{X}_{13}$ & -0.2 & 0.0 & 0.1 & 0.1 & -0.1 & -0.1 & -0.2 & -0.1 & -0.1 & -0.1 & -0.2 & 0.0 & -0.6 & 1.0 & \\
$\mathrm{X}_{14}$ & 0.0 & -0.1 & 0.0 & -0.1 & 0.2 & 0.2 & 0.4 & 0.1 & 0.2 & 0.1 & 0.3 & 0.2 & 0.8 & -0.7 & 1.0 \\
\hline & & & & & & & & & & & & & & \\
\hline
\end{tabular}

and $\mathrm{X}_{2}$ are of considerable correlations, i.e., 0.7 , the development of typology uses one of these variables. Accuracy tests were conducted where the chosen typology class are based on the highest overall accuracy (OA) score.

Development of a typology of forest cover changes The development of village typology was done using a clustering approach with standardized Euclidean distance (Standardized Euclidean Distance), and calculated with the following Equation [1].

$$
S d E D_{j k}=\sum \frac{\left(X_{i j}-X_{i k}\right)^{2}}{S_{i}^{2}}
$$

note: $s d E D_{j k}$ : standardized Euclidean distance; $S_{i}^{2}$ :the variance of the variable $I ; X_{i}$ : the value of the variable $i$ of the cluster $j$; Xik : the value of the variable $i$ of the cluster $k$

As for the technique in grouping the villages, the average linkage from the dendrogram method was used. To make it easier to conduct a classification analysis based on the level of similarity of each cluster size used, a technique is needed to compile a cluster clustering sequence, from a large number to a small number.This determined the closest distance between the members of each typology that were calculated based on the average values of the members within the group. Theclustering method has been successfully examined in previous studies (, Valbuena et al. 2008, Jaya 2010; Lastini 2012; Pang et al. 2013; Wijaya et al. 2015). Typology was based on selected variables from the correlation analysis which are $\mathrm{X}_{2}$ (proportion of forest area to the total area in each sample plot in 2015). To test the reliability of each class of village typology, then a spatial accuracy test was conducted based on the rate of classes of forest cover change.

Identification of driving forces Identification of the driving forces of forest cover change was processed using GIS spatial operation functions such as buffering, intersection, union, and clip. The buffering was done with 500-meter intervals to determine the distance attributes of the existing driving factors (Ahmad et al. 2015; Bennet 2015; Setiawan 2015; Sulistyono et al. 2015; Wijaya et al. 2015). Data for analyzing the driving forces were selected using the systematic sampling method with random start with the sampling intensity of $15 \%$, where each sample represents the area of $1 \mathrm{~km} \times 5 \mathrm{~km}$.

The number of selected samples were 285 samples. These data samples were then used for the standardization process of data, and model development at each using 95 samples. The rate of forest cover change was denoted as dependent variables (Y). Driving factors were expressed as independent variables $(\mathrm{X})$. The independent variables used in developing this model were distance of forest cover from the road $\left(\mathrm{X}_{1}\right)$, distance of forest cover from the river $\left(\mathrm{X}_{2}\right)$, distance of forest cover change from settlement $\left(X_{3}\right)$, distance of forest cover changes from plantation in 2000 $\left(\mathrm{X}_{4}\right)$, distance of forest cover change from plantation in 2015 $\left(\mathrm{X}_{5}\right)$, distance of forest cover change from agriculture in $2000\left(\mathrm{X}_{6}\right)$, distance of forest cover change from agriculture in $2015\left(X_{7}\right)$, distance of forest cover change from the edge of the forest in $2000\left(\mathrm{X}_{8}\right)$, distance of forest cover change from the edge of the forest in $2015\left(\mathrm{X}_{9}\right)$, and distance of forest cover change from sub-district capital $\left(\mathrm{X}_{10}\right)$.

Data standardization Prior develop the model, the model must have the ability to describe the weight for each driving factors, where all the driving factors had to be standardized, so the data used had the same scale and units. In this study, data standardization was conducted by converting the actual data values into scores. The transformation equation from the actual data values into scores was done using regression equation between each driving factors and the rate of each forest cover change. This conversion process could be done if the regression relationship of $\mathrm{X}$ and $\mathrm{Y}$ variables have $\mathrm{R}^{2}>$ $50 \%$. The scores generated based on that equation was made in a range of values between 10 until 100. To calculate the weight values of the model to always have a positive value, then the conversion equation from the actual data values to 
score was done using the equation as follows:

Equation [2] of score conversion with positive correlation coefficient is :

$$
\text { Skor }=\left(\frac{x-\min }{\max -\min }\right) \times 90+10
$$

The score conversion Equation [3] with negative correlation coefficient is:

$$
\text { Skor }=\left(\frac{\max -x}{\max -\min }\right) \times 90+10
$$

note: $x$ :The value of the relationship equation between driving forces and the rate of forest cover change; min and max: the lowest and highest value of the value of the driving factor

Development of forest cover change model Within each village typology, a spatial model by considering the forest cover change rates and their corresponding variables were analyzed through multiple regression analysis where driving factors were considered as the independent variables, and forest cover change rate was considered as the dependent variables. The selected model would have had to not only fulfilled the statistical requirements ( $\mathrm{p}$-value $<0.05$ and $\mathrm{R}^{2}>50 \%$ ), but also had to have the least value of validation error.

Model validation The model validation was intended to obtain the most optimum model through the model accuracy test (Jaya et al. 1995; Jaya 2010; Kumar et al. 2014; Muis et al. 2016). The best model accuracy test was conducted using data plot of 95 plots that were classified into three classes that follow the intervals of classes of the rate of forest cover change. To show the spatial distribution of the forest cover change, the rates of the change was classified into low, medium, and high. The accuracy assessments used were the overall accuracy (OA) that is naturally obtained from the confusion matrix and mean deviation (SR). The most optimum model selected would have the highest OA and SR.

\section{Results and Discusion}

\section{Village typology}

As depicted in Figure 1, the dendrogram distinctly classified the villages into two groups, then referred to as T1 and T2. The accuracy test result showed that the two typologies were closely related with the forest cover change rates. From the error matrix analysis, the study found that the villages could be divided into two typology classes having overall accuracy of $81 \%$ (Table 2). Village distribution map that includes $\mathrm{T} 1$ and $\mathrm{T} 2$ is presented in Figure 2.

Based on the proportion of forest, T1 had a proportion of forest $36.8 \%$, as for $\mathrm{T} 2$ had $75.4 \%$. From the forest cover change of view, T1 has a rate of 5,001.8 ha year-1 which was smaller than T2 that has $8,050.6$ ha year- 1 . This shows that the decline in forest area in each typology continues to occur and cannot be avoided. Forest stock in an area can affect the changes. Areas that have small forest stocks (T1) have a smaller rate of change than regions with large forest stocks (T2). The largest forest change for T1 is the conversions of forest to plantations and for T2 is to swamp scrub. In T1, changes in forest cover have become a lot of other covers, so the change rate is low. In T2, larger forest stocks makeforest cover changes higher due to forest conversion. The largest forest change for $\mathrm{T} 2$ is the conversion of forests into swamp shrub. Conversions into swamp scrub are thought to be largely unauthorized forest conversion. Graeub et al. (2016) and Austin et al. (2017) state that uncontrolled forest

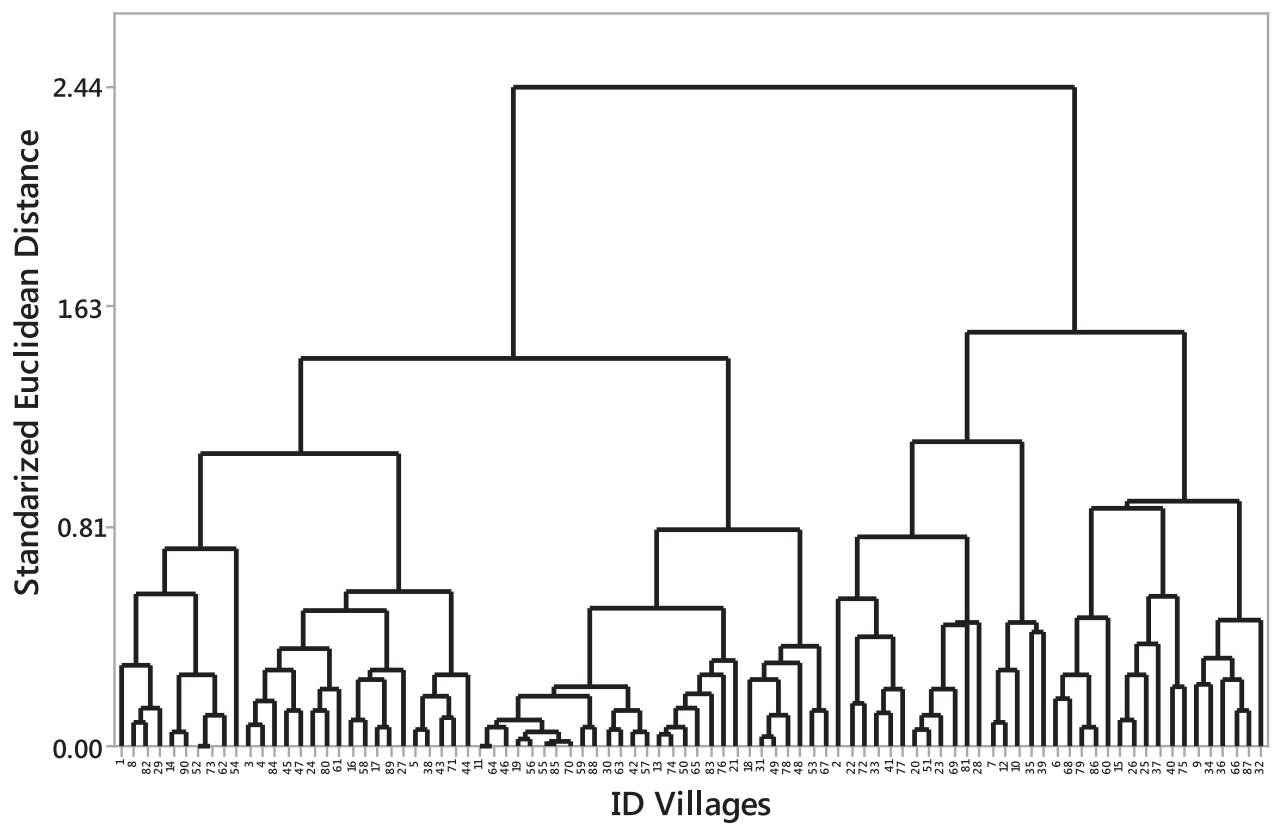

Figure 1 Dendrogram with proportion of forest in 2015 with average linkage method 
Table 2 Assessment results for accuracy of village typology grouping

\begin{tabular}{cc}
\hline Number of typology classes & Overall Accuracy $(\%)$ \\
\hline 4 Classes & 48.9 \\
3 Classes & 62.2 \\
2 Classes & 81.1 \\
\hline
\end{tabular}

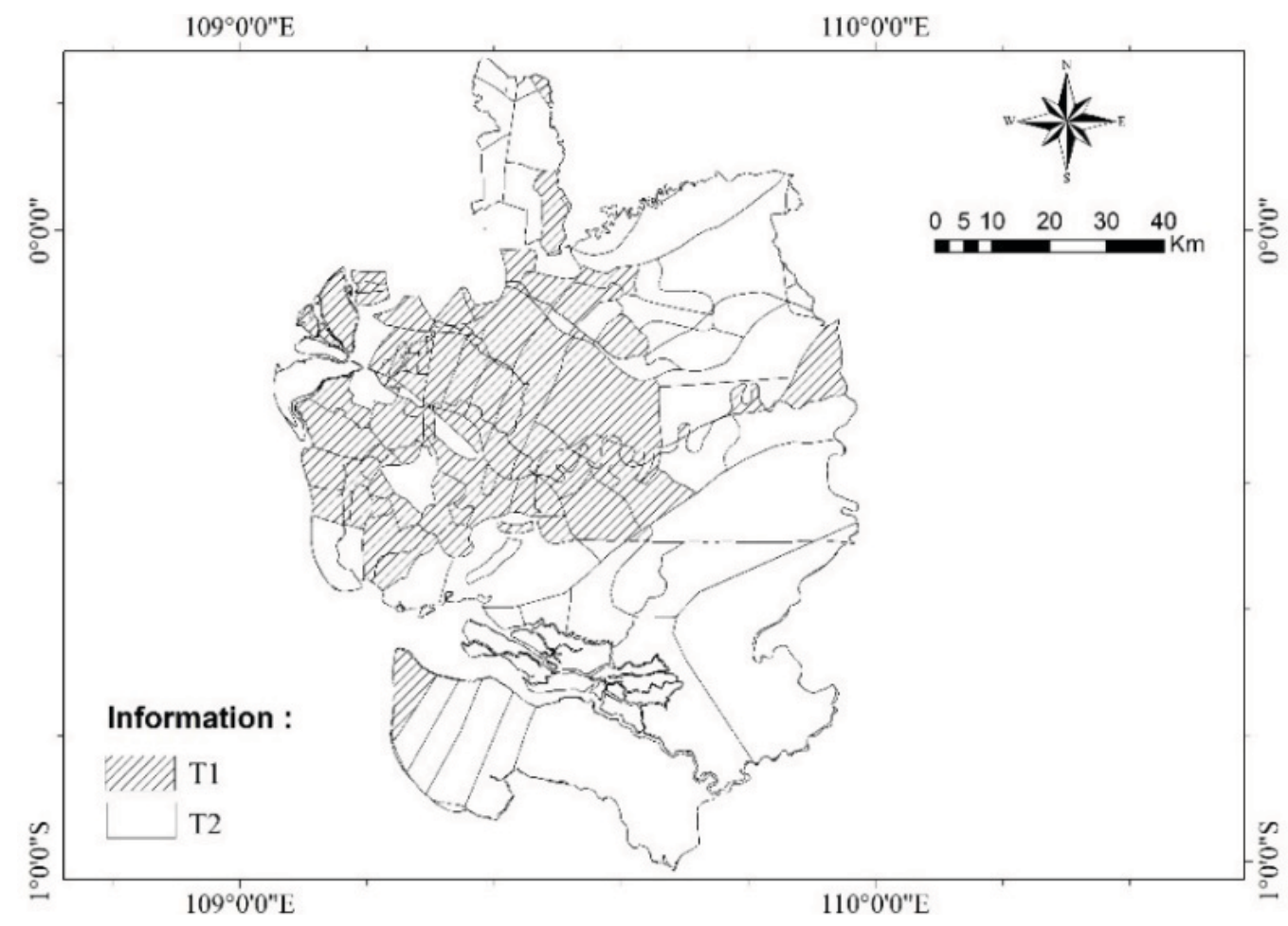

Figure 2 Distribution of villages in $\mathrm{T} 1$ and $\mathrm{T} 2$.

clearance can increase theforest cover change rates. The number of villages that included in $\mathrm{T} 1$ and $\mathrm{T} 2$ were 56 and 34 villages respectively.

Driving force of forest cover changes The selected variables of the driving forces ofchange for T1 and T2 were the variables that had a high value in determinant coefficients $\left(\mathrm{R}^{2}>0.5\right)$. The relationship between the change and each variable in $\mathrm{T} 1$ and $\mathrm{T} 2$ can be observed in Table 3 . The driving forces of change fromeach typology that were selected from Table 3 were then standardized by converting into scores. The selected driving forces were $\mathrm{X}_{1}, \mathrm{X}_{2}, \mathrm{X}_{3}, \mathrm{X}_{5}, \mathrm{X}_{6}, \mathrm{X}_{8}$, and $\mathrm{X}_{9}$. The result of the standardized variables from each typology is shown in Figure 3.

The variable of distance from the road in typology with high change rates (T2) showed that the closer the distance from forest edge to the roads, the larger the forest cover change rate since there is an illegal land encroached and land conversion (Figure 3a). The close distance between the forest areas and roads would easily facilitate the access (. 2014,
Mulyanto et al. 2004; Mahapatret al. 2005; Perez-Verdin et al. 2009; Wyman et al. 2010; Arekhi 2011; Kumar et al. 2014; Ahmad et al. 2015). Based on the conditions seen in the field, it was found that there were several accesses within the forest areas in the form of small paths that were often used and passed by the community. For the variable of distance from rivers, it only highly influenced by typology with low-cover change rates (T1) (Figure 3b). This might due to the fact, the closer area from the river are mostly privately owned land, in contrast, the further the distance from the rivers are mostly state-owned forest. The forest areas with closer distance to the river banks were still protected for conservation purposes (Deng et al. 2011; Lira et al. 2012).

The variable distance from settlements shows a different pattern for each typology (Figure 3c). In typology with lowforest cover change rates (T1) displayed that the farther the distance of forest areas to settlements, the smaller the effect of the change. There were smaller changes within forest areas that are further from settlements because the natural forest resources are a bit closer to the settlements. The 
Table 3 The equation for transforming the original value of each driving forces into score

\begin{tabular}{|c|c|c|c|}
\hline Typology & & Mathematical formula & $\mathrm{R}^{2}$ \\
\hline $\mathrm{T} 1$ & $\mathrm{Y}=0.00000000251 \mathrm{X}_{1}^{2}$ & $-0.000017024144 X_{1}+0.027222470352$ & 0.95 \\
\hline $\mathrm{T} 2$ & $Y=-0.00000000009 \mathrm{X}_{1}^{2}$ & - $0.000000118474 X_{1}+0.012429803765$ & 0.53 \\
\hline $\mathrm{T} 1$ & $Y=-0.00000000318 X_{2}^{2}$ & $+0.000019499388 \mathrm{X}_{2}-0.001985026757$ & 0.94 \\
\hline $\mathrm{T} 2$ & $Y=-0.00000003382 X_{2}^{2}$ & $+0.000199066163 X_{2}+0.053848857241$ & 0.27 \\
\hline $\mathrm{T} 1$ & $\mathrm{Y}=0.00011763751 \mathrm{X}_{3}^{0 .}$ & & 0.64 \\
\hline $\mathrm{T} 2$ & $\mathrm{Y}=-0.00000000015 \mathrm{X}_{3}^{2}$ & $+0.000001178696 \mathrm{X}_{3}+0.015096839342$ & 0.66 \\
\hline $\mathrm{T} 1$ & $Y=-0.00000000001 X_{4}^{2}$ & $-0.000000308959 X_{4}+0.022459076293$ & 0.33 \\
\hline $\mathrm{T} 2$ & $Y=0.00000000036 X_{4}^{2}$ & $-0.000002029254 X_{4}+0.153799602246$ & 0.35 \\
\hline $\mathrm{T} 1$ & $Y=-0.007135972 \ln \left(X_{5}\right)$ & +0.064012545043 & 0.73 \\
\hline $\mathrm{T} 2$ & $Y=-0.044273306 \ln \left(X_{5}\right)$ & +0.535760111409 & 0.12 \\
\hline $\mathrm{T} 1$ & $\mathrm{Y}=-0.003220283 \ln \left(\mathrm{X}_{6}\right)$ & +0.048778828928 & 0.72 \\
\hline $\mathrm{T} 2$ & $Y=-0.00000000168 X_{6}^{2}$ & $+0.000027153510 \mathrm{X}_{6}+0.168090078343$ & 0.08 \\
\hline $\mathrm{T} 1$ & $\mathrm{Y}=175.78262 \mathrm{e}^{-0.00068 \mathrm{X}} 7$ & & 0.33 \\
\hline $\mathrm{T} 2$ & $\mathrm{Y}=0.00000000278 \mathrm{X}_{7}^{2}$ & $-0.000024632469 X_{7}+0.265907741119$ & 0.48 \\
\hline $\mathrm{T} 1$ & $\mathrm{Y}=0.00000000119 \mathrm{X}_{8}^{2}$ & $-0.000009458233 X_{8}+0.016342389534$ & 0.51 \\
\hline $\mathrm{T} 2$ & $\mathrm{Y}=0.00000003094 \mathrm{X}_{8}^{2}$ & $-0.000188764886 X_{8}+0.255296771422$ & 0.62 \\
\hline T1 & $\mathrm{Y}=0.00000001526 \mathrm{X}_{9}^{2}$ & $-0.000068081686 X_{9}+0.291898116417$ & 0.83 \\
\hline $\mathrm{T} 2$ & $\mathrm{Y}=0.00000002504 \mathrm{X}_{9}{ }^{2}$ & $-0.000034535004 X_{9}+0.343130459328$ & 0.76 \\
\hline T1 & $Y=-0.00000000023 X_{10}^{2}$ & $2+0.000010999422 X_{10}+0.098412942415$ & 0.06 \\
\hline $\mathrm{T} 2$ & $\mathrm{Y}=0.00000000035 \mathrm{X}_{10}^{2}$ & $-0.000021645620 X_{10}+0.526875531666$ & 0.06 \\
\hline
\end{tabular}

distance fromnearbysettlements affects the timber quality (Lira et al. 2012). As for the villages in typology with highchange rates (T2) displayed that the closer the distance of forest areas to settlements, the larger the effect of change. $\mathrm{T} 2$ were villages with large forest areas. Villages with large forest areas tended to easily facilitate forest encroaching activities by the community (Perez-Verdin et al. 2009).

The distance from the plantation and the distance from agriculture only affects the rate ofchange rates in typology with lowchange rates or T1 (Figure 3d, Figure 3e). The closer the distance from the plantation, the higher the forest cover change rates. This can mean that plantation areasare getting closer to forest areas, and there have been conversions of forests to plantations, making it easier to enter the forests. This variable is in line with Wijaya et al. (2015) that the distance from the garden is a factor that influences the change of forest to non-forest in Jambi. On the other hand, the variable distance from agriculture shows that the farther the distance from agriculture, the higher the change rates. Based on observations in the field, in general, the location of agriculture is close to the edge of the main road, and this is inversely proportional to the existence of the forest, so that areas further from agriculture become closer to the forest and be converted as non-forest.

In typologies with lowchange rates (T1) and high (T2), the distance from the forest edge in 2000 (Figure 3f) shows similar trends. The closerto the forest edge the higher the change rateboth at $\mathrm{T} 1$ and $\mathrm{T} 2$. Variations in distance from the initial forest edge still have high forest stocks in each typology, changes in forest cover tend to spend the outer part of the forest first.
Similar trends were also found in the 2015 distance from the edge of forest in T1 (Figure 3g). The variable distance from the forest edge in 2015 shows that the farther from the edge of the forest, the higher the forest cover change rate. This shows that forests are increasingly being transformed into non-forests, so the changes that occur are farther away from the edge of the forest. However, in typologies with high rates of change (T2), the closer the distance from the forest edge in 2015, then the change rateis higher. This is because, in the high forest stock, the change patterns change at the closest distance to the forest first. Setiawan (2015) found that the distance fromforest edge is the most influential variable on deforestation. Wijaya et al. (2015) found that high deforestation tends to occur at close distances from the edge of the forest.

Spatial models of forest cover changes in $\mathrm{T} 1$ and $\mathrm{T} 2$ The spatial model was built based on the scores from selected variables through multiple regression analysis. Based on the result of the diversity analysis from the model, it was obtained several combinations of selected driving forces (independent variables) along with the accuracy test results presented in Table 4.

Based on the accuracy test, a combination that has an influence on forest cover change rates in $\mathrm{T} 1$ or typology with a low change rates is the distance from the river and the distance from the settlement, while in T2 typology withhigh change rates, were the distance from the road and distance from forest edge in 2015. The distance from roads, rivers, settlements, and the distance from the forest edge in 2015 
(a)

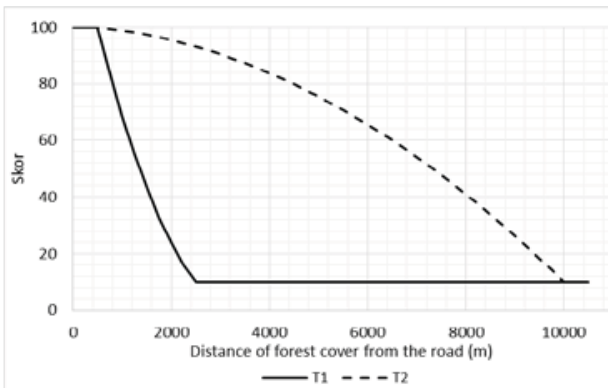

(c)

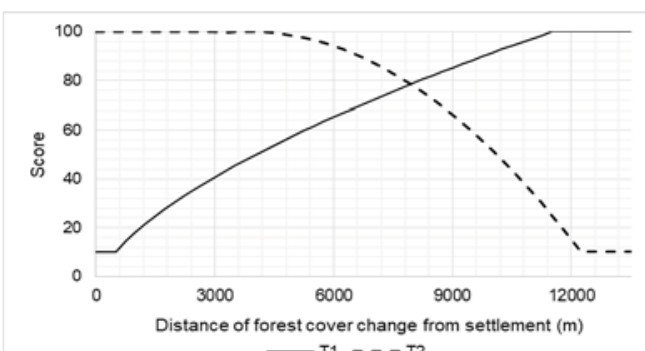
$-\mathrm{T} 1--\mathrm{T} 2$

(e)

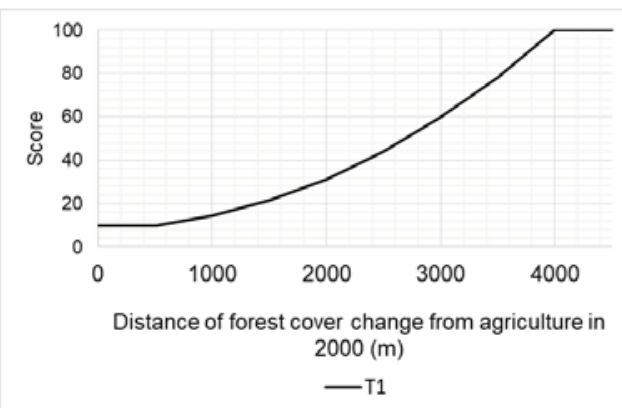

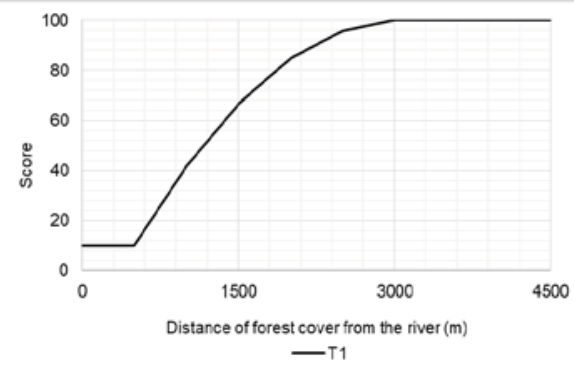

(b)

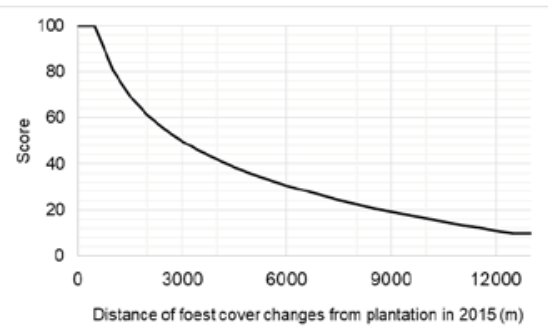

(d)

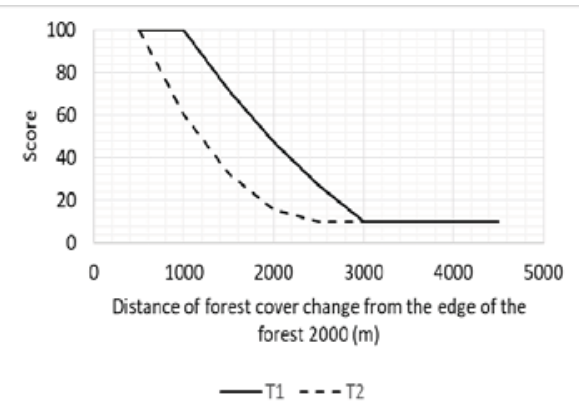

(g)

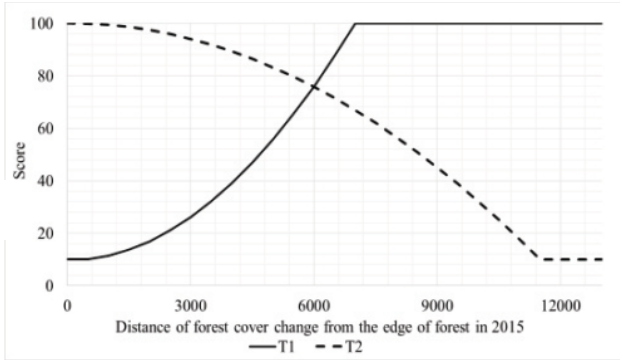

Figure 3 Relationship between score and model variables on T1 and T2. Distance of forest cover change from road (a); distance of forest cover change from river (b); distance of forest cover change from settlement (c); distance of forest cover change from plantation 2015(d); distance of forest cover change from agriculture in 2000 (e); distance of forest cover change from the edge of the forest in 2000(f); distance of forest cover change fromthe edge of forest in $2015(\mathrm{~g})$.

Table 4 Models of the driving forces and the rate of forest cover change

\begin{tabular}{clcc}
\hline Typology & Equation Model & OA (\%) & SR(\%) \\
\hline $\mathrm{T} 1$ & $\mathrm{Y}=-0.01+0.0001 \mathrm{X}_{2}+0.0004 \mathrm{X}_{3}$ & 83 & 10.5 \\
$\mathrm{~T} 2$ & $\mathrm{Y}=0.02+0.0001 \mathrm{X}_{1}-0.0002 \mathrm{X}_{9}$ & 53 & 13.3 \\
\hline
\end{tabular}


were the most influencing factor for the changesbecause it relates to accessibility into forest areas and the availability of forest resources (Wyman et al. 2010; Arekhi 2011; Wijaya et al. 2015).

Map of forest cover change The map was created based on the selected model from the result of multiple regression analysis of typology with low rates of changes (T1) and typology with high rates of changes (T2). The model for typology $(\mathrm{T} 1)$ wasY $=-0.01+0.0001 \mathrm{X}_{2}+0.0004 \mathrm{X}_{3}$ and typology $(\mathrm{T} 2)$ wasY $=0.02+0.0001 \mathrm{X}_{1}-0.0002 \mathrm{X}_{9}$. For(T1), the land cover change were lowly influenced by the distance from rivers and distance from settlements, as for (T2) were by distance from roads and distance from the edge of forest in 2015. Within the study site, the forest cover change were significantly influenced by the distance from roads $\left(X_{1}\right)$, rivers $\left(X_{2}\right)$, settlements $\left(X_{3}\right)$, and the edge of forest in $2015\left(X_{3}\right)$. These variables were suspected to have highly influenced the cover changes. This finding is in line with the previous study that have also stated that distance from roads, rivers, settlements, and the edge of forest in 2015 influencedforest cover changes and were one of the variables that have highly influenced the occurrence of the change (Wyman et al. 2010; .....et al. 2012; Ahmad et al. 2015; Wijaya et al.2015).

The result of the spatial operations showed several potential locations based on the suitability between the resulting model score and thechange rates as presented in Table 5. The results showed that forest cover change consisted of three classes, i.e. low, medium, and high. The locations of the percent classes of the change are displayed in Figure 4.

\section{Conclusions}

From the foregoing analysis and discussion, it was found that forest cover change rates differ between each village typology. Typology of changes at the village level in Kubu Raya Regency could be grouped into two typology classes with accuracy $81 \%$, i.e., typology 1 (T1) that had low change rate of 5001.8 Ha per year and typology 2 (T2) with high change rate with the average of 8050.6 Ha per year. Within the typology (T1) the model for forest cover change is $\mathrm{Y}=$ -

Table 5 The class division of the rate of change of forest cover

\begin{tabular}{lcr}
\hline $\begin{array}{c}\text { Forest cover change } \\
\text { classes }\end{array}$ & $\begin{array}{c}\text { Interval of forest cover change } \\
\text { (Ha per year) }\end{array}$ & $\begin{array}{c}\text { Forest cover changes (Ha per } \\
\text { year) }\end{array}$ \\
\hline Low & $0.4-1.6$ & 68462.6 \\
Middle & $1.6-2.8$ & 602411.1 \\
High & $2.8-3.9$ & 142926.6 \\
\hline Total & & 813800.3 \\
\hline
\end{tabular}

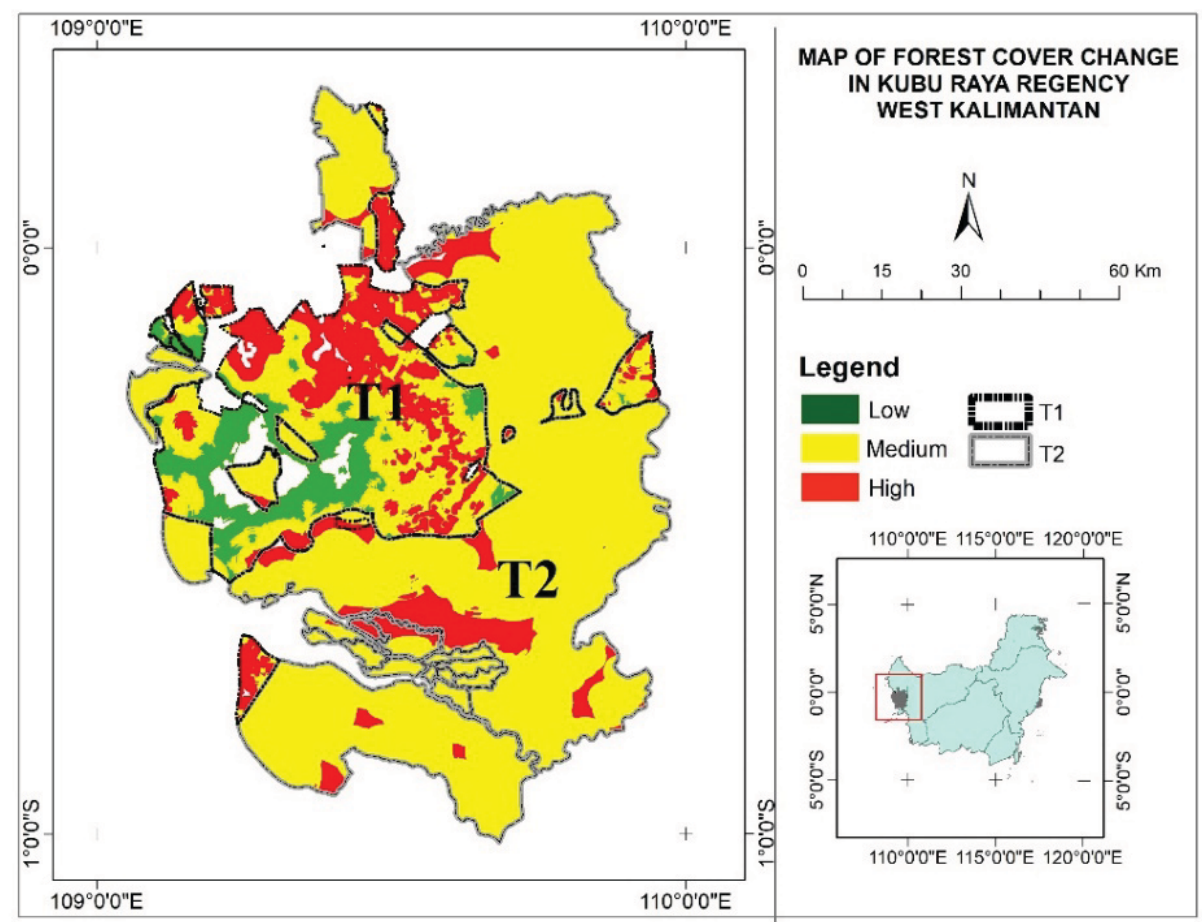

Figure 4 Map of forest cover change 
$0.01+0.0001 \mathrm{X}_{2}($ distance of forest cover from the river $)+$ $0.0004 \mathrm{X}_{3}$ (distance of forest cover change from settlement) with OA $83 \%$ and SR $10.5 \%$; while within the typology (T2) the spatial model is $\mathrm{Y}=0.02+0.0001 \mathrm{X}_{1}$ (distance of forest cover change from the road) $-0.0002 \mathrm{X}_{9}$ (distance of forest cover change from the edge of forest in 2015) with OA $85 \%$.

\section{References}

Ahmad A, Saleh MB, Rusolono T. 2015. Model spasial di KPHP Poigar, Provinsi Sulawesi Utara. Jurnal Penelitian Kehutanan Wallacea 5(2):159-169. https://doi.org/10.18330/jwallacea.2016.vol5iss2pp159169

Albar I, Jaya INS, Saharjo BH, Kuncahyo B. 2016. Spatiotemporal typology of land and forest fire in Sumatra. Indonesian Journal of Electrical Engineering and Computer Science 4(1):83-90. https://doi.org/10.11591/ ijeecs.v4.i1.pp83-90.

Arekhi S. 2011. Modeling spatial pattern of deforestation using GIS and logistic regression: A case study of northern Ilam forests, Ilam province, Iran. African Journal of Biotechnology 10(72):16236-16249. https://doi.org/10.5897/AJB11.1122.

Austin KG, Roglich MG, Smith DS, Schwanes AM, Swenson JJ. 2017. Trends I size of tropical deforestation events signal increasing dominance of industrial-scale drivers. Environmental Research Letters 12:1-12. https://doi.org/10.1088/1748-9326/aa7760.

Bennet G. 2015. Modelling regeneration and deforestation in the Atlantic Forest Brazil [thesis]. London: Imperial College London.

Deng X, Huang J, Uchida E, Rozelle S, Gibson J. 2011. Pressure cookers or pressure valves: do roads lead to deforestation in China. Journal of Environmental Economics and Management 61(1):79-94. https://doi.org/10.1016/j.jeem.2010.04.005.

[FWI] Forest Watch Indonesia. 2014. Potret Keadaan Hutan Indonesia Periode Tahun 2009-2013. Bogor: Forest Watch Indonesia.

Geist HJ, Lambin EF. 2001. What Drives Tropical Deforestation. A Meta-Analysis of Proximate and Underlying Causes of Deforestation Based on Subnational Case Study Evidence. LUCC Report series No. 4.

Graeub BE, Chappell MJ, Wittman H, Ledermann S, Kerr, Rachel B, Gemmill-Herren, Barbara. 2016. The state of family farms in the world. World Development. 87(C):1-15. https://doi.org/10.1016/j.worlddev. 2015.05 .012 .

[IPCC] Intergovernmental Panel on Climate Change. Climate Change 2013. The Physical Science Basis. Contribution of Working Group I to The Fifth Assessment Report of The Intergovernmental Panel on Climate Change. Cambridge: Cambridge University
Press.

Jaya I, Kobayashi S. 1995. Classification of detailed forest cover types based upon the separability algorithm: a case study in the Yahiko Mountain and Shibata Forest Area. Journal of the Remote Sensing Society of Japan 15(1):40-53.

Jaya INS. 2010. Analisis Citra Digital: Prespektif Penginderaan Jauh untuk Pengelolaan Sumberdaya Alam. Fakultas Kehutanan. Bogor: Bogor Agricultural University.

[KLHK RI] Kementerian Lingkungan Hidup dan Kehutanan. 2017. Perubahan tutupan hutan Indonesia tahun 2014-2015. Jakarta: Kementerian Lingkungan Hidup dan Kehutanan.

Kumar R, Nandy S, Agarwal R, Kushwaha SPS. 2014. Forest cover dynamics analysis and prediction modeling using logistic regression model. Ecological Indicators 45:444-455. https://doi.org/10.1016/j.ecolind.2014. 05.003 .

Lastini T. 2012. Tipologi Desa Hutan Rakyat: Kasus di Kabupaten Ciamis [dissertation]. Bogor: Bogor Agricultural University.

Lira PK, Tambosi LR, Ewers RM, Metzger JP. 2012. Landuse and land-cover change in Atlantic Forest landscapes. Forest Ecology and Management 278:80-89. https://doi.org/10.1016/j.foreco.2012.05.008.

Mahapatr K, Kant S. 2005. Tropical deforestation: a multinomial logistic model and some country-specific policy prescriptions. Forest Policy and Economics 7(1): 1-24. https://doi.org/10.1016/S13899341(03)00064-9.

Margono BA, Poapov PV, Turubanova S, Stolle F, Hansen MC. 2014. Primary forest coverloss in Indonesia over 2000-2012. Nature Climate Change. https://doi.org/10.1038/NCLIMATE2277.

Muis H, Jaya INS, Saleh MB, Mutilaksono K. 2016. Information required forestimating the indicator of forest reclamation success in ex coal-mining area. Indonesian Journal of Electrical Engineering and Computer Science 3(1):182-193. https://doi.org/10.11591/ijeecs. v3.i1.pp182-193.

Mulyanto L, Jaya INS. 2004. Analisis spasial degradasi hutan dan deforestasi: studi kasus di PT. Duta Maju Timber, Sumatera Barat. Jurnal Manajemen Hutan Tropika X(1):29-42.

Pang C, Yu H, He J, Xu J. 2013. Deforestation and Changes in Landscape Patterns from 1979 to 2006 in Suan County, D P R Korea. Forest 4(4):968-983. https://doi.org/10.3390/f4040968

Perez-Verdin G, Kim YS, Hospodarsky D, Tecle A. 2009. Factors driving deforestation in common-pool resources 
in northern Mexico. Journal of Environmental Management 90(1):331-340. https://doi.org/10.1016 /j.jenvman.2007.10.001.

Pincus NM, Ribe RG, Johnson BR. 2015. Spatially and socially segmenting private landowner motivations, properties, and management: a typology for the wildland urban interface. Landscape and Urban Planning 137:1-12. https://doi.org/10.1016/j.landurbplan. 2014.11.020.

Sarwono J. 2006. Metode Penelitian Kuantitatif dan Kualitatif. Yogyakarta: Penerbit Graha Ilmu.

Setiawan H. 2015. Model spasial deforestasi di Kabupaten Konawe Provinsi Sulawesi Tenggara [dissertation]. Bogor: Bogor Agricultural University.

Sloan S, Sayer JA. 2015. Forest Resources Assessmentof 2015 shows positive global trends but forest loss and degradation persist in poor tropical countries. Ecology Management 352:134-145. https://doi.org/10.1016 /j.foreco.2015.06.013.

Sulistiyono N, Jaya INS, Prasetyo LB, Tiryana T. 2015. Spatial model of deforestation in Sumatera islands using typological approach. Journal of Tropical Forest Management 21(3):99-109. https://doi.org/10.7226/ jtfm.21.3.99.

Valbuena D, Verburg PH, Bregt AK. 2008. A method to define a typology for agent-based analysis in regional land-use research. Agriculture, Ecosystems and Environment 128:27-36. https://doi.org/10.1016/ j.agee.2008.04.015.

Wijaya PA, Saleh MB, Tiryana T. 2015. Spatial model of deforestation in Jambi Province for the periode 1990-2011. Journal of Tropical Forest Management 21(3): 128-137. https://doi.org/10.7226/jtfm.21.3.128.

Wyman MS, Stein TV. 2010. Modeling social and landuse/land-cover change data to assess drivers of smallholder deforestation in Belize. Applied Geography 30:329-342. https://doi.org/10.1016/j.apgeog.2009. 10.001 . 